\title{
From preparedness to risk: From the singular risk of nuclear war to the plurality of all hazards ${ }^{1}$
}

\section{Introduction}

It may now be a given that we live in a risk society, in which thinking and acting in terms of risk is the dominant way of responding to contemporary uncertainty (cf. O'Malley 2004: 1). Beck's (1992) original claim and the analytical and methodological consequences that flow from it have been subject to voluminous interrogation, including in the pages of this journal. To give just the scantest of examples, this includes the impact (or not) of this apparent risk paradigm on how individuals understand their relationship to various forms of state provision (Taylor Gooby et al. 1999), on the composition of transnational forms of communality (Beck 2000), and on the aims and approaches of the social sciences themselves (Beck and Sznaider 2006), including in relation to such foundational analytical concepts as class (Beck 2013; Curran 2013).

But how are risks produced, exactly? This paper reopens this core sociological question in three ways. First, it argues that there is a need to shift attention away from the identity that is too often drawn between the production of risks and the deployment of explicitly calculative techniques and towards the durable instantiation of risk. Second, it suggests that it may in some cases be necessary to shift our understanding of the temporality of risk production, with some risks being produced not simply by the constitution of a threat, but by the very measures designed to prepare for or mitigate a perceived threat, potentially operating over the long term. And third, it makes a case for analysing the distinct ways risks are produced as respectively singular or plural.

The empirical grounds for this tripartite claim emerge from the comparative socio-historical analysis of the preparedness and civil defence practices of two nation states: Switzerland and the UK, over the course of a period spanning the late 1970s to the present. To some eyes, this may appear to be an unconventional comparison: ${ }^{2}$ the two countries have progressed down quite different geopolitical paths, they also differ considerably in their size and global influence, employ quite different systems of government and, importantly for our analysis, have pursued quite different national security strategies. Yet within Anglo-European security practices, Switzerland represents an under-appreciated counter-example against which to locate what became a dominant form of security orthodoxy during the period in question. During the Cold War, the US, the UK, and France all focused on protecting their populations from the threat of 
nuclear attack through a strategy of deterrence, with the US also supplying nuclear bombs to a range of other Western European countries (Lutz 2009: 97). Switzerland, however, while briefly considering building a nuclear deterrent, instead settled on a radically different and ostensibly more defensive approach, in its construction of a vast network of nuclear shelters for its population, an approach it pursued far more consistently and vigorously than others. ${ }^{3}$ As has been argued (Scarry 2011), Switzerland's approach marks a very different brand of 'emergency thinking' to the norms of the period, of which security practice in the UK is an exemplar. Putting these two countries into comparison therefore makes it possible to examine diverse responses to a threat that was, in major respects, shared. The material used to construct our comparison is mostly official government documents and archival material from the period, which variously chronicle the evolution of government risk assessment, alongside additional historical material from non-governmental actors who challenged these risk assessments.

We begin by delineating in more detail our understanding of risk production, showing not only that risk objects need to be constructed, but that that there are very different modes of producing and reproducing risk. We then guide the reader through the two cases, highlighting features that might be surprising for those who assume risk is born out of explicit acts of calculation. For it is a characteristic of both our cases that it is only in the last decades of the twentieth century that we begin to detect consistent and systematic attempts to compare risks of diverse kinds, ranging from natural disasters, to pandemics, to military threats. And here it is important to be absolutely clear that this had nothing to do with a lack of disasters in these countries or in other parts of the world up until this point. The story we tell depends on the fact that nuclear war, whatever its calculated risk, never happened and was only ever imagined. By contrast, in 1953 floods devastated several English regions, with a death toll of more than 500, with further floods occurring regularly in the years to follow. In 1965 in Switzerland, 88 people died when parts of a glacier collapsed and careered down a mountainside into the construction site of the Mattmark dam. Both countries also experienced deadly airline crashes, on their own territory and involving their airlines abroad. And both experienced so-called 'level 5' nuclear accidents during the Cold War including, in each cases, unintended radioactive emissions (UK: Windscale 1957; Switzerland: Lucens 1969). Crucially, however, neither these, nor the many other disasters that happened in the two countries, became the focus of comparative risk assessments until the 1980s. Indeed, our own short list already implies with hindsight which risks should be observed, made visible and compared, as if this were obvious from simply observing the unfolding of events. What we aim to show in this article, however, is that historically the 
opposite is true: whether any risk is made to exist, whether it is calculated and compared against other risks, cannot be inferred from the material or personal damage it produces, but from the history of its production.

In both our cases, the history of risk production involves a shift from the production of singular, non-comparative risks to plural risks, and therefore from non-comparative to comparative methods of risk assessment. First we focus on the production of singular risk, in particular in relation to the threat of nuclear attach. We show how in Switzerland nuclear risk was delegated into a highly durable network of bunkers and more or less evenly distributed, before we proceed to analyse the much more uneven production of nuclear risk in the UK. We then, second, jump to the final stages and aftermath of the Cold War, to analyse the production of plural risks by (state) experts. We demonstrate how in the UK comparing risks via an all hazards approach was seen as a problematic exercise in making civil defence acceptable to anti-nuclear campaigners and, further, how bringing different risks together in comparative analytical spaces created uncontrollable overflows of risks. We then proceed to the Swiss case and show how the persistent existence of bunkers made the shift to plural risks difficult, in part as new all hazards techniques seemed to reveal that the bunker network was superfluous.

\section{Producing risk}

Conventionally risk is understood to be produced and rendered amenable to analysis by a particular type of calculative act: the weighing of the relative magnitude of a potential loss due to a hazard against the probability of this hazard actually occurring (Beck 1992; Renn 1998; for overviews, see Clarke and Short Jr 1993; Tierney 1999). This is usually understood to be a quantitative exercise, or at least based around ideals of statistical measurement (Power 2007: 1314, Kalthoff 2005).

Much of the work that has moved away from this assumed relationship between the production of risk and calculative activity has sought to show how forms of risk analysis do not live up to the abstract ideal of methodologies of risk calculation. This includes those studies that have explored the way in which people, including experts, assess probabilities varies according to a range of conditions and norms (Kahneman 1982), or how the naming of something as a risk is an inevitably political process (Douglas and Wildavsky 1982; Tierney 1999; Van Zwanenberg and Millstone 2000). Relatedly, a number of studies have pointed out that the performance of risk 
calculation itself is both far from straightforward - risk is for instance seen as following its own organisational routines (Power 2004, 2007; Kalthoff 2005, 2011) - and a specific form of elite expertise subject to potential challenge by lay persons (McGoun 1995; Short 1984; Wynne 1994).

Yet despite pointing towards a diversity of ways in which risks are assessed, at the heart of these studies sit deliberate, explicit acts of risk calculation. It is posited that what is interesting about the assessments that surround the production of risk is that they are being made and that other forms of risk assessment may be valuable despite their non-quantitative format.

Not all work in the sociology of risk (broadly defined) has taken the relationship between calculation and risk at face value. Stephen Hilgartner argued early on that we should dispose of the idea that 'risk objects are objective features of reality' and should instead analyse how risk objects are constructed and displaced (Hilgartner 1992: 41). Ben Anderson, meanwhile, points to the existence of a range of risk-oriented techniques of future-making - scenario planning, for instance - that depend on what he calls 'acts of creative fabulation' (2010: 784).

The precise ways that such practices might occur have been subject to close scrutiny in relation to the object at the heart of this paper: socially and organisationally directed forms of preparedness. Much debate has centred on Beck's assertion that a characteristic feature of life in risk society is the very failure of the explicitly calculative techniques that themselves produce risk as an object of concern, that many of the risks that so-called second modernity produces escape calculation because of their sheer scale and the degree of uncertainty they embody - threats from industry, for example, or science, or, of particular relevance to this paper, defence (e.g. nuclear proliferation). Yet a particular technology of preparedness - insurance - has responded calculatively to exactly the kinds of large scale, uncertain risks which Beck focuses on (Aradau and van Munster 2011; Bougen 2003; Dean 2010; Collier 2008; Ericson and Doyle 2004; O’Malley 2004). Ericson and Doyle draw attention to the necessary interrelatedness of calculative and non-calculative techniques in insurance practices. This does not mean an absence of control, rather such practices are instead 'necessary expressions of authoritative certainty in face of limited knowledge, allowing definitive courses of action to be pursued' (Ericson \& Doyle 2004: 138). Stephen Collier, meanwhile, specifies a revised empirical project: studies of risk assessment should not be enquiring about the theoretical status of calculative rationality per se, but 'how risks judged 'uncertain' from one perspective are already being known and assessed using other approaches' (Collier 2008: 226 emphasis added). 
Part of what makes this debate important is that it highlights how risks are a more diverse coproduction than is often thought, involving not just a particular set of calculative techniques but a range of other forces and logics, ranging from non-calculative assessment methods to characteristic forms of governmental action. It also challenges the idea that, as Hilgartner puts it, 'the average speed with which risk objects are emplaced or displaced, are highest within communities of specialized professionals' (Hilgartner 1992: 51-52). Constructing risk objects through calculation needs expertise, and shifts in this process of construction can be quickly achieved by changing the 'practices of calculation' (Kalthoff 2006).

But the forces analysed in this body of work represent an incomplete empirical repertoire through which risk is routinely realised. In this paper we analyse the ways in which risks are subject to what we call 'concretisation' (see also Deville et al. 2014). With the term we refer to the potential for risks to be delegated into entities and processes that have a particular capacity to endure. It is particularly apt in our case, given much of our focus is on built solutions to risks that depend heavily on the material properties of concrete, as both a flexible and resilient building material. But the term could equally be applied to other processes in which, because of a potentially wide range of social and material forces, risks are produced in such a way (and here we draw on the broader sense of the verb) as to become obdurate and thus maintaining a certain consistency, over time.

Precisely how risk becomes active and actionable - whether by organisations or individuals depends on how it is translated into, remains within, and is potentially (re)activated by and through more or less solid objects. We here echo Rosemary Robins, who makes a case for accounts in which '[h] umans and their institutions figure as much as things in the world in generating and maintaining risks' (2002: 8). Part of the project is, then, simply adding to discussions on risk a greater attention to the role of materiality in risk's production and reproduction. In this respect, the article engages with a tendency in work on preparedness, security, and preemption to move away from seeing risk-oriented techniques of governmentality as narrowly epistemic affairs, to include the material within a wider set of empirical registers that are analysed. Attention has for instance been drawn to the agentic role of infrastructures in security practices (Aradau 2010), to the material constitution of, in particular, the threatening futures made actionable by and for governance techniques (Anderson 2010), and to the mundane materialities and affects of preparedness exercises (Anderson and Adey 2011). Within 
this work, there is also an increasing interest in the capacity for emergence that the material possesses. And yet, in our view, what this work largely does not do, is, first, to focus empirically on the ways in which the emergent properties of objects of risk-oriented techniques of government change over time and, second, to focus on the way in which the materialities of security practices do not just support but may actively hinder particular modalities of risk production. In this latter respect, this paper builds on Pierides and Woodman's (2012) work, which demonstrates the consequences emergent objects have for emergency management practices, showing how they interact and potentially interfere with one another. Analysing some of the ways risks are done allows us to see that it is the forms of practice through which risk is produced that defy calculation, not the risk objects themselves (e.g. nuclear power plants, for Beck). Or, to put it another way, if risk is neither just the outcome of epistemic and discursive operations, nor directly related to a particular set of risk objects, but is rather constituted through and shaped by more diverse socio-material ontologies than are usually accounted for, might preparedness activities not follow from the identification of risk through sets of knowledge practices but themselves change the terrain of risk? Might preparedness measures in fact generate apparently novel risks? Such a perspective indicates a shift away from the calculative question of 'likelihood' to the question of which risks (are made to) exist and endure. As we will show, the vexing question for social scientists is not so much whether historically some actors' calculations were correct or not, but rather why some risks were made to exist and endure, while others did not.

Before we begin to address these questions, a brief terminological note: many of the objects and practices this paper identifies as involved in the production of new risks and the ongoing reproduction of others have been named differently at different historical moments - and might include hazard, danger, disaster (mitigation), threat, resilience, preparedness, civil protection, civil defence, etc. Yet our goal is not to analyse how these different terms relate to different ideas of 'risk' (a perfectly worthwhile undertaking in its own right; see Collier (2008)), but instead to compare different modes of producing risk, leaving for present purposes various historical nomenclatures to one side. Above all, this article thus uses risk as an analytical term, rather than in relation to its specific uses in the historical periods being examined.

\section{Producing singular risk}

We turn now to our comparative, historically-attuned account. ${ }^{4}$ Our initial focus will be on comparing the respective production of 'singular' risk - as we will see in each of our two national 
cases, this involves a particularly strong focus by their respective apparatuses of government on one risk alone - in each instance nuclear war - to the near total exclusion of all others. Our comparison begins in Switzerland.

Switzerland: The universal concretisation of singular risk

Switzerland is a country with a history of concretised risk as a national project. Its extensive network of military fortifications, built in the central Alps from the end of the 19th century into the 20th, was the government's response to the threat of invasion, designed to form the material backbone for its reduit or 'redoubt' strategy (Berger Ziauddin 2009; Frey 2002; Halbrook 1998; Meier 2007). Rather than a conventional defence strategy, relying on raw superiority of arms and army size, the plan in the event of a conflict was for the government and military (note: not the population) to retreat into these fortifications and become hard to dislodge.

After the Second World War, Switzerland moved away from the asymmetrical protection of only military forces and government officials, in response to the perceived threat of global nuclear war. After briefly considering building a nuclear deterrent, the Swiss government settled on an ostensibly defensive response: a comprehensive network of nuclear blast resistant shelters for all Swiss inhabitants, both civilian and military. ' $[\mathrm{N}]$ o new house should be built without a shelter', it was proclaimed as early as 1949 (Aeberhard 1978: 63-66). Two years later, this ambition was fulfilled and put into effect in a new law (Meier 2007: 41-42), although it took until 1959 before the population provided its backing for the necessary constitutional changes.

This bunker building programme continued throughout the Cold War. By the 1970s, there were already enough shelter spaces for around 70 per cent of the population. New recruits to the contemporary Swiss civil protection force are now informed that there are enough shelter places for around 95 per cent of the population (Bundesamt für Bevölkerungsschutz 2004). This unusually comprehensive security system is made up of around 2,300 large public shelters and approximately 360,000 mostly smaller private shelters (Bundesamt für Zivilschutz 2012).

The programme changed the material fabric of Switzerland's built environment, with consequences that we will document. But it also introduced a new calculative set of approaches into the heart of Swiss civil defence, although it would take decades before attempts were made to apply similar principles to a broader canvas of security problematics. As Silvia Berger 
Ziauddin has documented, in attempting to provide a set of universal design principles for the Swiss bunker in the early 1960s, researchers were faced by a range of calculative problems, including (but by no means limited to):

What kind of atomic weapon should be used in the calculations? What happened, when a bomb exploded with a caliber larger than the 20 kilotons used in Japan? What detonation height, what distance from ground zero should the calculation be based on? (Berger Ziauddin 2009: 4)

Coming up with a credible bunker design inevitably required an involvement of engineers and computer scientists to calculate what were a series of unanswerables (Berger Ziauddin 2009: 5). Explicit calculative techniques were also used to justify the bunker network's very existence: using probability theory, the head of the programme, Ernst Basler, ran scenarios to compare the chances of population survival with and without the bunker system (Berger Ziauddin 2009: 6). This leads to, as Berger Ziauddin puts it,

The near miraculous conclusion...that, at a cost of around 1000 [Swiss] Francs per person, and a structural protective capacity of at least $1 \mathrm{AT}$...the number of casualties by the attack of any weapon could be reduced to a tenth, representing an efficiency rating of $90 \% !^{5}$ (Berger Ziauddin 2010)

Calculation was thus central to the Swiss civil protection programme of the 1960s and 1970s. This included applying forms of probability analysis to weigh the impact of different scenarios (Switzerland either with or without bunkers) against one another.

However, when looking back at the broader civil defence programme of the period, it is evident that such calculative fastidiousness did not extend to weighing which threats to its security the Swiss nation should pay attention to in the first place. Absent at this point in time are explicit calculations weighing the risk of nuclear war against a plurality of risks. ${ }^{6}$ Where evidence of comparative assessment is to be found, the calculative practices at play appear rather loose, and the object of comparison rather limited. Take the following, an extract from the 1966 report on the then new set of strategic defence objectives:

Should Switzerland become involved in a war in the near future, it will with the greatest probability [mit grösster Wabrscheinlichkeit] involve a total war, which will be played out 
either around the deployment of weapons of mass destruction, or the constant threat of such a deployment. If there are now certain signs of a loosening of relations within the existing power blocks, which as a consequence could increase the probability [die Wabrscheinlichkeit ... zunehmen könnte] of limited conflicts conducted using conventional weapons, then - as long as stocks of weapons of mass destruction exist in individual countries - such clashes would nonetheless carry within them the seed of larger, nuclear-led wars [Original emphasis, authors' translation] (Schweizerischen Bundesrat 1966: 857).

The object of comparison is limited to a single domain - defence - and concerns an assessment of the likelihood of nuclear as compared to conventional war impacting Switzerland.

What we initially saw with the reduit and what becomes more explicit as we move through the twentieth century history of Swiss civil defence: that assessments of threat - whether quantitative or not - is only one way in which risk is produced as an object of government and public attention. This includes the delegation of risk assessments into durable objects, whether the reduit fortifications or the bunker building programme. As we will show, when risk is concretised in this way, it becomes particularly susceptible to becoming transformed over time as it enters into relation with changing logics of expertise.

Switzerland is certainly not exceptional in the narrow frame of its risk assessment practices. What does set it apart, however, is that its lack of comparative attention was made material, visible, and omnipresent. Often the absence of a comparison between risks may pass unnoticed, only to be rendered visible after a catastrophic event. But the Swiss bunkers, despite being the product of a sophisticated calculative apparatus, were the built incarnations of the absence of plural risk assessments. Or, to put it positively, they themselves became key components of Switzerland's singular risk assessment: they were evidence of the decision to focus civil protection nearexclusively on an atomic threat without explicitly comparing this threat to others.

\section{The UK: Nuclear shelters: The asymmetrical concretisation of singular risk}

Because of the UK's geopolitical role during the Cold War, including being an active member of NATO, compared to Switzerland it was clearer it could be subject to direct Soviet attack. Its response was more overtly aggressive: rather than a system of shelters, it focused on building a system of nuclear deterrence. By building its arsenal of nuclear weapons and associated organisational and material infrastructure, other nuclear powers would, it was posited, be 
dissuaded from attacking for fear of reprisals (thus the UK simultaneously played its role in entrenching nuclear risk as a global matter of concern).

The problem for the UK government was that this apparently protective infrastructure could not answer the questions that would inevitably arise about what would happen if there was a nuclear conflict. (Nuclear) protection became difficult to frame as something that either should only occupy governmental attention prior to a conflict or could be solved by solely building an ultimately offensive capability, whose primary stated purpose was to protect.

As already noted, the UK's approach was of course not unique in comparison to other influential world powers (see also Vale 1987). However, whereas in the Soviet Union and the USA nuclear deterrence was coupled to at least the tokenistic state-led provision of shelters for their populations, the UK government provided its population very little in the way of protection. In the 1980s, it had no autonomous civil protection organisation, having already disbanded (or formally mothballed) the UK's only autonomous civil protection organisation - the Civil Defence Corps and Auxiliary Service - in 1968, citing budgetary constraints (Woolven 2007: 17). The primary way the state interacted with the population in relation to the potential effects of a nuclear attack was by playing the role of a provider of information, with a predominant focus on advising the households on how best to protect themselves. This involved guidance on how to construct a material shell that might provide protection in the event of a nuclear attack. This information, distributed via leaflets including, famously, the 'Protect and Survive' series (HMSO 1980), included various recommendations on how to block windows with books, protect parts of a building with sandbags, as well as on the benefits of digging underground shelters in gardens, and constructing improvised inner refuges in homes, using furniture and bin bags.

As those working in civil defence had already known since the mid-1950s, and as many British inhabitants quickly surmised, these methods would likely be inadequate in the face of a nuclear blast. The government had its own experimentally derived evidence: it showed an unfeasible 27 inches worth of books against a window would be required to offer a measure of protection (Smith 2010: 173). Similarly, planners realised that surrounding buildings with sandbags would have required a national stock of 2000 million; the existing stock was 30 million (Smith 2010: 174). 
Nevertheless, even with the logic of deterrence, it remained clear that some people would need to be protected in the event of a strike, in order for the deterrent to remain fully operational. The government did therefore build a number of high spec protective nuclear shelters. However these were explicitly designed without the broader population in mind, being restricted to key military and governmental personnel. Like the Swiss reduit, these were aimed at keeping the UK state and armed forces (if not much of its population) safe and operational in the event of a conflict, in part to enable the coordination of any retaliatory nuclear action. These command and control centres included a set of distributed bunkers, so called Regional Seats of Governance (RSGs), connected by their own communication infrastructure.

Like Switzerland, the UK had undertaken a very narrow 'singular' risk assessment, with the same focus: the nuclear threat posed by other nations. Yet the response was quite different: nuclear risk was concretised in a combination of a nuclear deterrent which was claimed to be able to offer the population protection (by forestalling conflict) and a small network of bunkers designed to offer protection (by providing a secure material shell), but only for key officials.

This concretised risk assessment had a secondary effect. It entrenched an ethical response to the problem of survival posed by the nuclear threat. The protection on offer became radically asymmetrically distributed, with a clear cleavage between the protection respectively offered to state/military officials and the population. The resultant inequalities in the provision of protection were first made public in the 'the spies for peace' episode in 1963, in which the existence of a particular Regional Seat of Governance - RSG-6 - was revealed by activists (Anon 1963). Later, the journalist Duncan Campbell provided a more extensive exposé of the system in his book War Plan UK: The Truth About Civil Defence in Britain (Campbell 1982: 180-224). One of Campbell's targets is the government's defence of its lack of public shelter provision, a defence, it is worth noting, that deploys calculation as a justificatory tool. The first defence was that 'the risk of war is at present considered so slight that the enormous expense of providing shelters to every family in the land could not be justified'; the second, was that there had in fact been millions of pounds worth of expenditure on civil protection, including $£ 45$ million spent in $1983 / 84$, and that this expenditure could be considered as an "insurance premium" against the remote risk that NATO's continuing deterrent policy might fail' (Campbell 1982: 467). As Campbell notes, comparing this figure ${ }^{8}$ with the billions spent by Switzerland, ${ }^{9}$ if shelters for the wider population represents an 'insurance premium', then 'it is not [one] the government is 
prepared to pay' (Campbell 1982: 467). For Campbell, and potentially for his readers, the Swiss bunkers, by standing as a point of contrast, provided the proof that the cost was payable.

For both the UK and Switzerland, nuclear risk was understood as singular. However, when it comes to how this risk assessment was materialised, the stories diverge. Unlike in Switzerland, the UK cemented, both in its architectural response and in its approach to population governance, a very visible asymmetry of protection. Any universal form of protection that deterrence might provide by preventing war (a highly contested claim in itself), could not obscure the fact that, if this logic failed, the possibility of survival would be distributed unevenly. A ruling class would be safe in state of the art nuclear shelters, with the ruled left cowering under tables and staircases, perhaps surrounded by a hastily assembled assortment of household materials.

Calculation, meanwhile, is not absent: as we have seen, a calculative logic was mobilised by the British government in discussions around the 'insurance premium' represented by their civil defence expenditure. However, it is a logic that reveals its fragility when confronted by the more durable shelters built by either the British government for its officials or the government of another country.

\section{From singular to plural risks}

Thus far our focus has been on what we have referred to as 'singular' risk assessments. These involve weighing risk in relation to a single threat, in which calculative efforts focus on the different possible outcomes that might come from the simple presence or absence of any mitigatory measure. At no point in our story thus far has the question occurred as to either whether there were other risks that should be considered, or whether the money spent and the infrastructures built would be better or more efficiently used to prepare for other such risks.

A consistently plural understanding of risk cannot begin to be detected until later in the histories of each country, in their respective adoption of methods associated with what is now recognised as the 'all hazards' approach to disaster planning. ${ }^{10}$ In the UK the process began in the mid1980s, while in Switzerland, it took place in the period following the de facto end of the Cold War, in the early 1990s. It is important to understand that in each case this shift cannot be explained by the sudden presence of new threats. Indeed, as we will show in a moment, while 
nuclear war was the risk that should occupy both governmental and public attention, it did not occur. At the same time, numerous disasters that caused injuries, death and damaged infrastructure, did occur, ranging from landslides, to floods and chemical accidents. However, for almost the entirety of the Cold War period, we found no evidence of state actors in our two cases producing these second sets of events as risk objects on an equal footing with military risks.

This was set to change, as we will now show by continuing to follow the UK as it moves out of the Cold War and by revealing the nascent development of all hazards and the tensions that resulted. This involved a shift in attention from single to plural risks, ultimately turning the previously singular risk into one among many, rendering it relative, open to critique, and, potentially, allowing it to be ignored by preparedness altogether.

\section{UK: Producing plural risks through lists}

The all hazards approach to disaster management has now become fairly standard in the preparedness practices of governments and other agencies. As Andrew Lakoff has documented in his history of the rise of all hazards in the USA, the aim was to bring a range of potential catastrophes 'into the same operational space' (Lakoff 2007: 262). ${ }^{11}$ The rise of 'risk maps' is one prominent example of this (Jordan 2012). These involve the deployment of visualisations that attempt to define different risks via their comparative relationship to one another, along axes of probability and perceived impact.

What has now become a routine way in which risk is produced as an object of governmental action was something both far more political and far less tied to specific calculative procedures in the earlier histories of our two cases. Producing objects as risks, and bringing them into the same comparative plane can be a contentious practice, in particular when encountering previous ways in which risk is instantiated.

How this shift came to pass in the UK requires some brief historical contextualisation. UK civil protection in the early 1980s was beset by tensions between central and local government about who would pay for even basic nuclear attack preparedness measures. Central government had the power to regulate civil protection and attempted to force local councils to act accordingly. However central government would not pay for these efforts, giving (left-leaning) local councils 
some clout in resisting the provision of civil defence, which they saw as connected to a pronuclear deterrence stance (Arnold 2008).

All hazards offered central government an apparent solution to this impasse. It could be used to suggest that civil defence was not just about nuclear risk, but all kinds of preparedness. Many on the political left viewed this with cynicism, seeing it as another way of justifying the delegation of responsibility for nuclear protection away from central to local government (see for instance, Labour MP Bruce Millan's contribution to a 1983 parliamentary debate (Anon 1983: 388)). From this perspective, 'all hazards' was to be opposed not on the basis of bow it assessed risk, or for bringing new risks into the purview of governance - responsibility for civil disasters was already held locally - but because it seemed to legally shift the responsibility for (nuclear) risk through forms of mitigation to local government.

For those on the other side of the political spectrum, all hazards was equally problematic, but for different reasons. In 1985 the cross party pressure group National Council for Civil Defence (NCCD) published a report rooted in the principles of all hazards seeking increased state spending for civil defence (Trebah Trust 1985). One commentator writing for the right-leaning Institute for Civil Defence warns that all hazards will 'divert NCCD from its aims, primarily because it is easier to get lost once you have muddied the pure stream' (Meads 1985: 27; emphasis added). Ultimately, the article concludes, 'Civil Defence [with its focus on nuclear attack] has its own favourable arguments, which can defeat its opponents, without any need for the All Hazards Approach' (Meads 1985: 27). For the right, all hazards was again criticised - but in question is not the distribution of responsibility for nuclear risk, but the very integrity and 'purity' of civil defence as being focused on a singular risk.

The effects of such opposition were limited. In 1986 the Civil Protection in Peacetime Act was passed, which granted local governments permission to use civil defence infrastructure for peacetime disasters, although still without funding from central government. Long-term opponents of all hazards were forced to accept the new reality. Bruce Sibley, for example, editor of the journal Practical Civil Defence (PCD), announced that the publication would now 'accommodate “All-Hazards” topics' (Sibley 1986: 3), describing the 'PCD's readership's concern with the growing menace of industrial accidents, vehicular and aircraft crashes, quakes, floods, drought, port and refinery explosions, medical emergencies and terrorist action....' (Sibley 1986: 3). 
Risk was being recomposed as an inherently plural entity, which, as we see from Sibley, now required individual risks to be named and defined. At this stage, however, there is little advancement in the calculative techniques that might be used to weigh this newly plural risk landscape. Instead, authors simply listed risks (see also: de Goede 2014; de Goede, Leander and Sullivan 2016). And these lists, similar to those in the previous Sibley quote, began to appear everywhere.

One prominent type of list that began to emerge in the later 1980s and early 1990s was the 'disaster table’ (Walsh 1989; Emergency Planning College 1994; Parker and Handmer 1991a: 275-278). ${ }^{12}$ A group of disaster professionals were becoming increasingly upset with government policy and responded by producing a number of books and articles with a radically different perspective. Their lists and thus their discussions of risk focused on actual past disasters, rather than a disaster (nuclear war) that was feared by so many but had never happened. They traded the future for the past, or, in their view, ideology for practical, dispassionate analysis.

The disaster table served the essential purpose of naming these actual disasters and bringing them into a comparative analytical space. Let us look at one such table in detail (Figure I), published in 1991 (Parker and Handmer 1991a: 275-276). First, the list only covers disasters that actually occurred. Preparedness and disaster response switches from the imagined and the total to the small and actual. Second the list includes only 'selected' events. The authors thus had no intention of creating a statistical, calculative measure of risk, but instead sought to highlight a political point through selection. Selection appears as innocent, but is obviously crucial: why these disasters and not others? Third, the list does not concern disasters in Britain, but disasters 'affecting' Britain. This means Chernobyl is included, a disaster that occurred thousands of miles away. The mitigation of such a threat suddenly becomes only partially, if at all, influenceable by British politics (Chernobyl could not be 'deterred'). Fourth, the disasters are categorised. The categories do not conform to the Cold War civil defence classification of atomic war vs. the rest. Rather, they refer to kinds of disasters which each relate to their cause (and not to risk as a measure of likelihood and severity). Fifth, this kind of list and practice of categorisation produces an overflow. It opens the door to a potentially endless list of plural risks: 'We should be conscious', the authors Handmer and Parker write, 'that the range of hazards and disasters could and should be expanded further, for example to include medical ones such as those arising 
from harmful side effects of drugs such as the arthritic drug Opren' (Parker and Handmer 1991b: 262).

Figure I: 'Selected Major Accidents and Disasters Affecting the UK'

\section{[INSERT FIGURE I AROUND HERE]}

The list composes risk as a plural, comparable entity, given particular force by how a series of statements about risk are visually and comparatively presented. This produces the opposite effect of the nuclear war-related singular productions of risk, which exclude by their imagined totality all other disasters that, by comparison, appear flimsy. If annihilation is on the horizon, why would the state bother about a few train accidents? The reversal of the temporal arrow from future to the past creates an avalanche of risks: if total annihilation may never happen, what are the risks for which the state should prepare? The disaster list turns this from, ironically, a certainty about the future, into an empirical problem of the past. But at the same time, the overflow returns the empirical problem into a conceptual one: If past and known events rather than assumed future events should guide preparedness, which risk objects should be constructed? If it does not follow from past events that we can determine what counts as risk, then how can we know for which future risks we should prepare?

The focus on past events changed the future from a single assumed risk into multiple and ultimately unknown risks. These tables can be seen as the beginning of a long history of conflicts about what should count as a risk, and about what the role of the state in mitigating, preparing and pre-empting such risks should be. In the UK, this leads in 2001 to an organisation primarily concerned with civil disasters, the 'civil contingencies secretariat', which was set up before the attacks in the US on September $11^{\text {th }}$ as a response to flooding and the threat of the millennium bug. It was followed from 2008 onwards, by the publication of 'national risk registers', with a primarily civil focus (Cabinet Office 2008). Seen historically, the list's analysis of the surrounding risk landscape did not close down but opened up the issue of how to do risk assessments. And crucially, as the following contrast with Switzerland renders clear, it is precisely the fact that nuclear risk in the UK was not delegated into widespread, visible and durable structures that allowed risk to overflow in this manner. These lists were not overly influenced by existing forms of concretised nuclear risk, given that private bunkers were invisible and scarce and government bunkers were discredited and largely hidden from public view. Neither had enough force to 
influence which risks would be included in risk tables and risk registers. As we will now see, in Switzerland, while we can observe the same shift to multiple risks, existing concretised risks had implications for which kinds of risks would be enumerated.

\section{Switzerland: Total defence encounters plural risk}

In the aftermath of the Second World War, the central doctrine of Swiss security strategy became providing the nation with a 'total defence' (Gesamtverteidigung). Unlike the UK, this philosophy did not allow for an easy separation between military and civilian security. 'Defence', a euphemism for all forms of military activity, was held to include civilian protection in equal measure (see Frey 2002; Schweizerischen Bundesrat 1966; Schweizerischer Bundesrat 1973). The Swiss shelter and the concept of 'total defence' were therefore deeply, even intrinsically, connected.

However, after the end of the Cold War, this strategy lost its symbolic referent. The idea that one risk could self-evidently justify the total defence concept could not be sustained. A key public flash point was an ultimately unsuccessful referendum that took place in 2000, called: 'Making savings on military and total defence: For more jobs suitable for peace and the future'. The long-standing Swiss way of doing civil defence was under threat not just from changing popular opinion, but also from the development of a new form of risk assessment. This was an approach that, akin to all hazards, was grounded in the careful and considered analysis of a plurality of risks.

Two contrasting visualisations, both from major security reports that each attempt to mark a shift towards a new national security and preparedness 'concept' capture the changing approaches: the first is published in 1990, not long after the end of the Cold War, the second in 1999, the year before the referendum. In the first (Figure II) we see that, at a time when in the UK vastly different risks began to be compared freely, there is instead a simple bifurcation of risk: into 'power political dangers' and 'remaining existential dangers'. This division attempts to present two quite distinct types of risk. Yet, with both being subject to potential mitigation by the 'means of total defence', there is a clear ambition to make the case that the end of the Cold War does not mark a radical break point. The ambition is rather to adapt the existing total defence infrastructure to this newly dual understanding of risk. 
Figure II: 'Existential Security and Security Policy'

[INSERT FIGURE 2 AROUND HERE]

Source: Schweizerischer Bundesrat 1990: 855.

By the 1999 report this bifurcation of risk has disappeared, replaced by a de facto all hazards approach. The report is replete with references to risk as multifaceted, requiring a 'flexible' response irrespective of whether it is military or civilian. This apparent shift is again captured in a visualisation (Figure III), which sees military and non-military risks all contained in a single formless blob—all within the same operational plane.

As we have already seen in the UK, there is no necessary correspondence between producing risk as plural and the development of calculative techniques capable of conclusively weighing such plurality. In Switzerland this is not the case. In the years leading up to the 1999 report, attempts were indeed made to couple the recognition of the plural character of risk to explicitly calculative techniques. This involved a research project, commissioned in 1992, whose aim was to design new methodologies for assessing and comparing nationally-significant risks, in which military and geo-political risks were to be placed on the same analytical plane as other risks, with the latter as diverse as natural disasters, migration, and economic shocks. The results, seven years in the making, were gathered together in a report - Risk Profile Switzerland - that was due to be published in 1999, in the same year as the new security conception was to be launched. Contained within its almost 150 pages was a detailed and calculatively derived comparison of the 34 types of event thought to pose the greatest existential risk to Switzerland (see Figure IV), an approach radically different to what had been seen not just in the previous security reports but in the corpus of preceding government-produced literature.

Figure III: 'Schematic Representation of our Security Policy Strategy: Security Through Cooperation'

[INSERT FIGURE III AROUND HERE]

Strategic aims 
Source: Schweizerischer Bundesrat 1999: 7687.

However, the report was suppressed, because of what came to be seen as the controversial nature of its content. This remains a significant and widely recalled event within Swiss civil protection governance, as revealed in a number of interviews with current and former civil protection officials. It was the apparent promise of risk analysis to be able to rank risks quantifiably, objectively and, in particular, bierarchically and in public that became problematic. After a presentation on an interim report in front of some media representatives, a popular current affairs programme ran a story on the project and commented on a number of the report's scenarios. ${ }^{14}$ It also reproduced a chart drawn directly from the report that seemed to compare the likelihood and impact of different risks with one another (and is thus analogous to many contemporary risk maps; see again Figure IV). It focused on the apparently low risk of (by implication, 'conventional') military conflicts in contrast the diverse range of other risks made present. ${ }^{15}$ The relevant column was then highlighted, as per the version below.

According to the recollections of Herbert Braun, who headed up the project, the response from within government was almost instant. ${ }^{16}$ 'There was hell' within the defence department, with his superior, Adolf Ogi, berating him over the telephone and a ban being put on the release of information about the project. As Braun put it,, their decision was 'yes, you may proceed, but please, in heaven's name, don't put any more information into the public'.

Figure IV: Comparing Swiss riskes ${ }^{17}$

\section{[INSERT FIGURE IV AROUND HERE]}

This new technique seemed to tie an ostensibly objective, dispassionate calculative methodology to the allocation of resources in a way that threatened the infrastructure of total defence, of which the most obviously vulnerable was the military. ${ }^{18}$ It was this possibility that seemed to have led to the decision to keep the report locked away. It also led to the exclusion in the final (unpublished) report of the kinds of comparison of different risks within the same operational space, of the kind represented by the above chart. ${ }^{19}$ This was part of the price that needed to be paid in order to defend the post Cold War residuals of total defence. Perhaps the success of this move can be measured by the fact that, despite some opposition, to this day, the requirement to 
build fallout shelters in new buildings remains. The concretisation of risk into concrete, nuclear bunkers is thus, in Switzerland at least, an ongoing practice.

\section{Conclusion}

In this article, we have shown that by moving away from conceiving risk as indelibly related to calculation to instead analysing the diverse production of risk, we can begin to understand the quite different pathways through which it can emerge. We began by arguing that risk should be conceived as being produced not only calculatively, but also materially and, within that, in relation to its capacity to be made to endure. We then proceeded to track these distinct forms of risk production comparatively across two cases: the UK and Switzerland. We focused on the shift from Cold War nuclear defence to an all hazard approach. In both national cases, we showed that in our cases this shift cannot in any simple way be accounted for either by the waning of one kind of threat and the emergence of others, or by the emergence of new forms of calculation. Indeed, a curious feature of both cases is that their shifts to all hazards also occur because of very basic and, on the face of it, insubstantial forms of risk production - through lists and diagrams.

In both cases, the shift from nuclear war to all hazards involves struggles concerning a shift from the presence of single to plural risks, with this struggle shaped by the forms of durable risk materialisation that had been deployed (or not) in preparation for nuclear war. In Switzerland, the extensive system of bunkers erected during the Cold War, designed to ideally protect each and every citizen, hindered the shift to all hazards, with all hazards' way of both understanding and calculating risk threatening to make the bunker system dispensable. In the UK, there was a period in which it was the visible asymmetries of concretised protection led to debate and ridicule, once the secret system of bunkers for the elite was exposed and contrasted to the largely Do-It-Yourself approach to preparedness promoted to the public by the state. In the longer term, however, the more consequential actors in shifting the terrain of risk in the UK were more mundane and far less concrete - simple risk lists. Unencumbered by the kind of architecturally ubiquitous but increasingly anachronistic instantiation of state security strategy to be found in Switzerland, the focus in the UK was not on the validity of techniques far more simple than those used in Switzerland, but rather on the financial and political demands that these emergent risks made of government. All hazards in the UK thus became a political dispute in part 
concerning which arm of the state - central or local - was to pay to protect the population from a newly diverse landscape of risk.

From this comparison also follows an important observation, equally relevant to both countries: it does not follow that because risk calculations are technically possible, they are then undertaken. Rather, risk materialisations, and particularly the kinds of concretised risk materialisations in both our cases, can be strong impediments to the calculation of risks, even by state sanctioned experts. Even from the point of view of some experts, there are times when it is better not to know about or not to invoke risks. ${ }^{20}$ As we outlined earlier, it has been repeatedly observed that risk calculation is not a neutral, apolitical undertaking. Part of what our twin story shows, then, is that, even as organisations promote the calculation of risk as a neutral tool in order to advance their own agenda, its very practice can disrupt the smooth progress of these organisations.

At the same time, we have revealed a surprising shift in the temporal relationship between practices of preparedness and risk production. Conventionally, it is assumed that preparedness follows from risk: that first a risk is identified and that then, in response, preparedness measures become implemented. Yet we have shown how residues of previous preparedness measures themselves become implicated in recomposing and stabilising or destabilising novel risk terrains. To put it simply, in such instances the direction of travel is from preparedness to risk.

Our account is therefore not about disputes over how to do 'proper' risk assessments. Rather it is about decisions as to whether risks should be produced and stabilised through particularly durable materialisations of risk. This also points towards a different role for social scientists as critical analysts of risk production: the problem is not so much about uncovering hidden assumptions about the technicalities of how risk is being calculated, but about developing an awareness of the precise means, and the variable degrees of concretisation, of forms of risks production. Once produced, risks can possess their own momentum, which may not have a clear relation to other risks that they come into interaction with. The problem, then, is not the unwarranted security and confidence of seemingly apolitical expert practices, but rather deciding how we want to produce, or not produce, risks. This also includes the tricky question of how much societies should aim to include and build on previous ways that risk is made durable. Risk 'calculations' in this sense are not only calculations about the likelihood and severity of certain risks, but whether existing productions of risk warrant preparing for certain risks or not. 
Living in a risk society, then, does not equate to everything becoming a potential risk object according to a specific set of techniques and forms of expertise. The characteristic features of risk society might instead be considered as the socio-historically contingent outcomes of different modes of producing risk that have interacted across time and space to produce a particular set of regularities. In this process, there is always the potential for previous modes of (re)producing risk to prevent certain objects from becoming risk objects. The future extension of the present set of conditions is by no means assured. The contemporary dominance of risk maps, risk registers, and expert-led, calculative forms of dealing with threats may, our analysis suggests, in time shift to other ways of producing risk. For example, the ever-more myopic focus by diverse governments on a range of 'wars on terror' carry with them echoes of the past singular production of risk during the Cold War. ${ }^{21}$ The role of sociology and social science more broadly may thus be not just to analyse how specific techniques produce ever changing risk objects. Rather, it might both insist on the complicity of experts in producing risk objects and help prevent one risk from once again displacing all others.

\footnotetext{
1 This paper draws on research conducted as part of the 'Organising Disaster' project, funded by the European Research Council (project number 263731), which we would like to thank for its support. We would also like to thank the four anonymous reviewers, Silvia Berger Ziauddin, Nigel Dodd, David Eugster, Zuzana Hrdličková, Monika Krause and Sibylle Marti for their very helpful comments on earlier drafts of this paper. We would also like to thank for their helpful suggestions the audiences at two seminars at the LSE - CARR and Catastrophic Urbanism: Disaster, Emergency, Cities - and those at both the Innovation in Governance seminar at the TU Berlin and the Political Anthropology of Switzerland conference at the University of Zurich.

2 This is something that, in and of itself, should not be a bar to comparative practice, as we have argued elsewhere (Deville, Guggenheim and Hrdličková 2016).

${ }^{3}$ As we will come on to discuss, Switzerland's network of bunkers is the most extensive in the world, in theory able to house close to 100 per cent of its population. That said, some European countries have attempted similar programmes, with Sweden and Finland reported to have built enough bunkers to house 81 per cent and 70 per cent of their populations respectively; the next closest is Austria, on 30 per cent (Scarry 2011: 60).

${ }^{4}$ Our account necessarily proceeds at times through abrupt temporal jumps. Its aim is not - nor could it be given space constraints - to provide a comprehensive history of the entire period in question.
}

\footnotetext{
${ }^{6}$ We have found no evidence of such a risk assessment in the archival records. This would be very surprising given that, as we will discuss, such a methodology was only developed in the 1980s. As already noted, other disasters did exist, including the 'disaster winter' of 1950-1951 (Pfister 2002: 155-167), the 1986 Schweizerhalle chemical disaster, as well as the Mattmark disaster presented in the introduction.

7 There was also a scattershot of other nuclear bunkers built by councils, but neither did these ever aim to protect the general population, nor were they built according to government standards. There are at present about 300 nuclear bunkers known (including the RSG), across the whole of the UK; see the various documentation hosted at Subterranea Britannica (www.subbrit.org.uk)

8 '[E]ven in 1982/83, they had yet (in real terms) to exceed the spending in some of the 'low years' of the mid 1970s' (Campbell 1982: 467).
} 


\footnotetext{
9 'By 1980, Switzerland had spent $\$ 2.4$ billion and constructed six million shelter places, together with supporting facilities. They plan to spend $\$ 4$ billion between 1980 and 2000.' (Campbell 1982: 467).

10 We prefer to refer to 'plural' rather than 'multiple' risks in our analysis. Even if risk objects are inevitably multiple (on which see Robins 2002), our focus is on a highly specific ways in which they are rendered as such via organisational procedures that produce risks comparatively (e.g. via lists or all hazards assessments). Associating these procedures and their products with the language of, and debates around, ontological multiplicity would, in our view, confuse matters for readers unnecessarily.

${ }^{11}$ Also see Boudia and Demortain (2014) for a broader account of how risk analysis was formalised and made generic during the 1970 s and 80 s in the US.

12 An important earlier attempt to bring notable civil disasters into comparative relation is Barry A. Turner's book Man Made Disasters (1978). The author places historically occurring British disasters alongside one another, for the most part to attempt to draw out potentially shared pre-conditions. This however differs substantially from the approaches discussed here, given that Turner puts disasters into comparative relation primarily to demonstrate commonalities in their causes, rather than seeking to open up the very category of what, in the first place, should 'count' as a disaster.

${ }^{13}$ This initiative followed the more radical initiative to abolish the army altogether which was voted on in 1989.

1410 vor 10 . Broadcast 8th November, 1995.

${ }^{15}$ Or, to translate more literally: 'warlike events' (kriegerische Ereignisse).

${ }^{16}$ Interview, conducted in German on 12th April 2013. All translations our own.

${ }^{17}$ Original title: 'Preliminary risk profiles of the scenarios, taking into account their expected impacts and frequency of occurrence' (Zentralstelle für Gesamtverteitigung 1995: 7).

${ }^{18}$ See Cavelty and Hagmann (Hagmann and Cavelty 2012: 84). This was also Herbert Braun's view.

${ }^{19}$ Interview with Herbert Braun.

${ }^{20}$ On strategic ignorance, see McGoey (2012).

21 A particularly noteworthy example of this is the Trump administration's strong policy focus on perceived terror threats, coupled with significant increases in military expenditure, at least partially funded by a heavy curtailing of funding to agencies concerned with the analysis and management of a range of other risks, whether for example financial (Gara 2017) or environmental (Pettypiece and Dlouhy 2017).
}

\section{Bibliography}

Anderson, B. and Adey, P. 2011 'Affect and Security: Exercising Emergency in "UK Civil Contingencies", Environment and Planning D 29(6): 1092-1109.

Aeberhard, R. 1978 Zivilschutz, in der Schweiz, Frauenfeld: Huber.

Anderson, B. 2010 'Preemption, Precaution, Preparedness: Anticipatory Action and Future Geographies', Progress in Human Geography 34(6): 777-798.

Aradau, C. 2010 'Security That Matters: Critical Infrastructure and Objects of Protection', Security Dialogue 41(5): 491-514.

Aradau, C. and Van Munster, R. 2011 Politics of Catastrophe: Genealogies of the Unknown, London: Routledge.

Arnold, J. 2008 'Hot War in the Town Halls: Nuclear Free Zones and Local Authorities in the 1980s'. Paper presented at Peace Movements in the Cold War and Beyond: An International Conference, 1-2 February, London School of Economics, London.

Beck, U. 1992 Risk Society: Towards a New Modernity, London: Sage. 
Beck, U. 2000 'The Cosmopolitan Perspective: Sociology of the Second Age of Modernity', The British Journal of Sociology 51(1): 79-105.

Beck, U. 2013 "Why "Class" is Too Soft a Category to Capture the Explosiveness of Social Inequality at the Beginning of the Twenty-first Century', The British Journal of Sociology 64(1): 63-74.

Beck, U. and Sznaider, N. 2006 'Unpacking Cosmopolitanism for the Social Sciences: A Research Agenda', The British Journal of Sociology 57(1): 1-23.

Berger Ziauddin, S. 2009 'Die Apokalypse als Forschungsimpuls: Schweizerische “Totalverteidigung" und das Forschungsinstitut für militärische Bautechnik im Kalten Krieg', in DGGMNT-Jahrestagung (Conference). DGGMNT-Jahrestagung, Hannover.

Berger Ziauddin, S. 2010 'Wahre Schweizer Architektur ist unterirdisch - oder wie die Schweiz im Kalten Krieg zum Schutzbaumusterland wurde', in. Historisches Seminar, Universität Stuttgart.

Boudia, S. \& Demortain, D. 2014. La Production d'un Instrument Générique de Gouvernement. Gouvernement et Action Publique 3(3): 33-53.

Bougen, P. 2003 'Catastrophe Risk', Economy and Society 32(2): 253-274.

Bundesamt für Bevölkerungsschutz 2004 Der Zivilschutæ: Grundlagen, Auftrag, Einsatz, Bern: Bundesamt für Bevölkerungsschutz. Available at: http://www.bevoelkerungsschutz.admin.ch/internet/bs/de/home/dokumente/aubildungsun terlagen/der_zivilschutz_.parsys.0003.downloadList.00031.DownloadFile.tmp/derzivilschutz04d.pdf (Accessed: 19 January 2016).

Bundesamt für Zivilschutz 2012 Schuţbauten. Available at: http://www.bevoelkerungsschutz.admin.ch/internet/bs/de/home/themen/schutzbauten.ht ml (Accessed: 19 July 2011).

Cabinet Office 2008 National Risk Register. Available at: http://www.cabinetoffice.gov.uk/resource-library/national-risk-register (Accessed October 11, 2011).

Campbell, D. 1982 War Plan UK: The Truth About Civil Defence in Britain, London: Burnett.

Civil Defence 1983. Available at: http://hansard.millbanksystems.com/commons/1983/oct/26/civil-defence-1 (Accessed: 5 March 2012).

Clarke, L. and Short Jr, J. F. 1993 ‘Social Organization and Risk: Some Current Controversies', Annual Review of Sociology 19(1): 375-399. 
Collier, S. J. 2008 'Enacting Catastrophe: Preparedness, Insurance, Budgetary Rationalization', Economy and Society 37(2): 224-250.

Curran, D. 2013 'Risk Society and the Distribution of Bads: Theorizing Class in the Risk Society', The British Journal of Sociology 64(1): 44-62.

Danger! Official Secret. RSG - 61963 Spies For Peace. Available at: http://www.bl.uk/learning/images/21cc/counterculture/large8866.html (Accessed: 9 August 2013).

Dean, M. 2010 Governmentality: Power and Rule in Modern Society, London; Thousand Oaks, CA: Sage Publications.

Deville, J., Guggenheim, M. and Hrdličková, Z. 2016 'Introduction: The Practices and Infrastructures of Comparison', in J. Deville, M. Guggenheim and Z. Hrdličková (eds.) Practising Comparison: Logics, Relations, Collaborations. Manchester: Mattering Press, 17-44. Available at: https://www.matteringpress.org/books/practicing-comparison (Accessed: 28 February 2017).

Deville, J., Guggenheim, M. and Hrdličková, Z. 2014 'Concrete Governmentality: Shelters and the Transformations of Preparedness', in M. Tironi, I. Rodriguez-Giralt and M. Guggenheim, (eds.) Disasters and Politics. Materials, Preparedness and Governance, London: Wiley (Sociological Review Monograph), 183-210.

Douglas, M. and Wildavsky, A. 1982 Risk and Culture: An Essay on the Selection of Technical and Environmental Dangers, Berkeley: University of California Press.

Eidgenössisches Departement für Verteidigung 1999 Risiko-profil Schwei : Umfassende Risikoanalyse Schweiz. [Unpublished document].

Emergency Planning College 1994 A Digest of Some Well-Known Disasters, Easingwold: Emergency Planning College.

Ericson, R. V. and Doyle, A. 2004 'Catastrophe Risk, Insurance and Terrorism', Economy and Society 33(2): 135-173.

Frey, S. 2002 Switzerland's Defence and Security Policy During the Cold War (1945-1973), Lenzburg: Verlag Merker im Effingerhof.

de Goede, M. 2014 'The List as a Technology of Emergency Governance', Paper presented at Governing Emergencies Workshop, $23^{\text {rd }}$ September, Royal Geographical Society, London.

de Goede, M., Leander, A. and Sullivan, G. 2016 'Introduction: The Politics of the List' Environment and Planning D: Society and Space 34(1): 3-13.

Gara, A. 2017 'Trump to Propose 10\% Defense Increase in Budget Plan, Aides Say' Bloomberg, 27 February. Available at https://www.bloomberg.com/politics/articles/2017-02- 
27/proposed-trump-budget-said-to-boost-defense-spending-cut-epa (Accessed 28 February, 2017).

Hagmann, J. and Cavelty, M. D. 2012 'National Risk Registers: Security Scientism and the Propagation of Permanent Insecurity', Security Dialogue 43(1), 79-96.

Halbrook, S. P. 1998 Target Switzerland: Swiss Armed Neutrality in World War II, Rockville Centre, NY: Sarpedon.

Hilgartner, S. 1992 'The Social Construction of Risk Objects: Or, How to Pry Open Networks of Risk', in J. Short and L. Clarke (eds.) Organizations, Uncertainties, and Risk. Boulder: Westview Press, 39-53.

HMSO 1980 Protect and Survive. Available at: http://www.atomica.co.uk/main.htm (Accessed: 9 February 2011).

Jordan, S. 2012 ‘A Short History of Risk Maps, or Why Do We Find Risk Maps Appealing?’, Risk and Regulation Winter 2012, (24): 20-21.

Kahneman, D. 1982 Judgment Under Uncertainty: Heuristics and Biases, Cambridge; New York: Cambridge University Press.

Lakoff, A. 2007 'Preparing for the Next Emergency', Public Culture 19(2): p. 247.

Lutz, C. 2009 The Bases of Empire: The Global Struggle against U.S. Military Posts, London: Pluto Press.

McGoey, L. 2012 'Strategic Unknowns: Towards a Sociology of Ignorance', Economy and Society 41(1): 1-16. doi: 10.1080/03085147.2011.637330.

McGoun, E. G. 1995 'The History of Risk "Measurement”, Critical Perspectives on Accounting 6(6): 511-532. doi: 10.1006/cpac.1995.1047.

Meads, R. 1985 'Review: Civil Defence Briefing Guide', The Journal of the Institute of Civil Defence 48(July-September): 27-28.

Meier, Y. 2007 Die gesellschaftliche und institutionelle Verankerung des schweizerischen Zivilschutzes in den 1950er und 1960er Jahren. Der Zivilschutz. als Ausdruck des ambivalenten schweizerischen Selbstverständnisses im Kalten Krieg. PhD. Universität Freiburg.

O’Malley, P. 2004 Risk, Uncertainty and Government, London: GlassHouse.

Parker, D. and Handmer, J. W. (eds.) 1991a Hazard Management and Emergency Planning: Perspectives on Britain, London: James \& James.

Parker, D. and Handmer, J. W. (eds.) 1991b 'Improving Hazard Management and Emergency Planning', in Hazard Management and Emergency Planning: Perspectives on Britain, London: James \& James, 261-274. 
Pettypiece, S., Dlouhy, J. 2017 'Trump’s EPA Budget Cuts May Unleash a Backlash as Risks Remain', Bloomberg, 27 February. Available at https://www.bloomberg.com/news/articles/2017-02-27/trump-s-epa-budget-cuts-mayunleash-a-backlash-as-risks-remain (Accessed: 28 Feburary 2017).

Pfister, C. 2002 Am Tag Danach. Zur Bewältigung von Naturkatastrophen in der Schweiz. 1500-2000, Bern: Haupt.

Pierides, D. and Woodman, D. 2012 'Object-oriented Sociology and Organizing in the Face of Emergency: Bruno Latour, Graham Harman and the Material Turn', The British Journal of Sociology 63(4): 662-679.

Power, M. 2007 Organized Uncertainty: Designing a World of Risk Management, Oxford; New York: Oxford University Press.

Raaflaub, C. 2005 'Mattmark: Dunkle Seite der Baugeschichte', swissinfo.ch. Available at: http://www.swissinfo.ch/ger/archiv/Mattmark:_Dunkle_Seite_der_Baugeschichte.html?cid= 4701184 (Accessed: 20 March 2013).

Renn, O. 1998 'Three Decades of Risk Research: Accomplishments and New Challenges', Journal of Risk Research 1(1): 49-71.

Robins, R. 2002 'The Realness of Risk: Gene Technology in Germany’, Social Studies of Science 32(1): 7-35. doi: 10.1177/0306312702032001002.

Scarry, E. 2011 Thinking in an Emergency. New York: W.W. Norton \& Co.

Schweizerischen Bundesrat 1966 'Bericht des Bundesrates an die Bundesversammlung über die Konzeption der militärischen Landesverteidigung', Bundesblatt 1(24): 853-877.

Schweizerischer Bundesrat 1973 'Bericht der Bundesrates an die Bundsversammlung über die Sicherheitspolitik der Schweiz (Konzeption der Gesamtverteidigung)', Bundesblatt 1973 II, 112 153.

Schweizerischer Bundesrat 1990 Schweizerische Sicherheitspolitik im Wandel: Bericht 90 des Bundesrates an die Bundesversammlung über die Sicherbeitspolitike der Schweiz. Available at: http://www.parlament.ch/d/dokumentation/dossiers/sipol/Documents/sipol-90-061bericht-d.pdf (Accessed: 20 August 2011).

Schweizer Radio und Fernsehen 2000 Armee-Reform. Available at: http://www.srf.ch/player/video?id=14d52abf-5c2a-4104-8cec-31e3f9c1b9cf (Accessed: 15 August 2013).

Short, J. F. 1984 'The Social Fabric at Risk: Toward the Social Transformation of Risk Analysis', American Sociological Review 49(6): 711-725.

Sibley, B. 1986 'A New Look...', Practical Civil Defence, 3. 
Smith, M. 2010 'Architects of Armageddon: The Home Office Scientific Advisers' Branch and Civil Defence in Britain, 1945-68', The British Journal for the History of Science 43(2): 149-180.

Taylor-Gooby, P., Dean, H., Munro, M. and Parker, G. 1999 'Risk and the Welfare State', The British Journal of Sociology 50(2): 177-194.

Tierney, K. J. 1999 'Toward a Critical Sociology of Risk', Sociological Forum 14(2): 215-242.

Turner, B. A. 1978 Man-made Disasters, London; New York: Wykeham Publications; Crane, Russak.

Vale, L. J. 1987 The Limits of Civil Defence in the USA, Switzerland, Britain and the Soviet Union the Evolution of Policies Since 1945, Basingstoke: Macmillan.

Van Zwanenberg, P. and Millstone, E. 2000 'Beyond Skeptical Relativism: Evaluating the Social Constructions of Expert Risk Assessments', Science, Technology \& Human Values 25(3): 259-282.

Walsh, M. 1989 Disasters: Current Planning and Recent Experience, London: Edward Arnold.

Woolven, R. 2007 'UK Civil Defence and Nuclear Weapons: 1953-1959’, UK Nuclear History Working Paper 2. Available at: http://www.mcis.soton.ac.uk/Site_Files/pdf/nuclear_history/Working_Paper_No_2.pdf (Accessed: 18 December 2012).

Wynne, B. 1996 'May the Sheep Safely Graze? A Reflexive View of the Expert-Lay Knowledge Divide', in S. Lash, B. Szerszynski and B. Wynne (eds.) Risk, Environment and Modernity: Towards a New Ecology, London: Sage, 44-83.

Zentralstelle für Gesamtverteitigung 1995 Rechenschaftsbericht über das Projekt Umfassende Risikoanalyse Schweiz. Bern: Zentralstelle für Gesamtverteitigung. 